\title{
An Empirical Study on MOOC-based College English Model in China
}

\author{
Qin Wang \\ School of Foreign Languages \\ Shaanxi Normal University \\ Xi'an, China
}

\begin{abstract}
The present study was designed to explore MOOCbased college English model in China. The paper outlines the basic role of teachers and students in the model and reports the major findings from a one-semester teaching practice in a university in China. Likert Scales, questionnaires and interviews are used in the study. Qualitative and quantitative data suggest that MOOC-based College English teaching is widely accepted by college students. It offers flexibility, various online resources, and virtual communication to students' English learning. The paper also discusses some problems of the model which are worthy of consideration: the requirement and burden to the teachers; the supervision and assessment; and some other limitations of MOOC-based College English model.
\end{abstract}

Keywords-MOOC; FC; college English model; English teaching; Writing; Course design

\section{INTRODUCTION}

Education technology means using of modern technology for creation and management of education to improve the students' performance [1]. Since the rise of MOOC (Massive Open Online Courses) in China, this new technology throws light on college English Education and changes traditional way of college English teaching. A large number of online courses bring new thinking to education in China. We can't ignore the reality that there still exist controversial issues about MOOC courses, which include the lacking of sustainability, missing of face-to-face communication and low rate of completion [2]. However, the advantages of MOOC courses do cast light on traditional college English learning. While many pioneers are seeking a great way to combine traditional teaching and MOOC-based learning, most papers focus on theoretical thinking and evidence from empirical studies is not sufficient. This paper does an empirical study on MOOC-based college English teaching mode. It focuses on the systematic design of MOOC-based College English model. Randomly chosen classes and students are involved in the study for a whole semester. Students' performance, data and questionnaire analysis altogether show some great evidence and useful suggestions on MOOC-based College English teaching and learning.

\section{MOOC AND COLLEGE ENGLISH}

To start the paper, it's necessary to make a simple introduction of MOOC and traditional college English teaching in China.

\section{A. College English Teaching in China}

College English is a compulsory course for students of any major in all the universities and colleges in China. It's usually a four-semester compulsory which is thought necessary and difficult for all the students. Though it has a long history and broad audience, it's usually thought time-consuming and unsuccessful. In order to change the controversial reality, many reforms have been taken. But from the point of teachers and students, college English teaching is still unsatisfactory $[3,4]$. The following issues are obvious to see:

1) Lacking of teaching facilities and resulted problem of class size. College English classes in China are commonly conducted in a large class, usually over 50, sometimes over 100 even 200. So it's not easy for any class activity. It's usually thought language class should be conducted in a small class. But for the lacking of teaching facilities, including teachers and some other facilities, class-size reduction is not possible for college English teaching in China.

2) Traditional way of college English teaching vs. multimedia time and young students' way of learning. In this fast changing time, students are exposed to modern technology every day and they already make multi-media a part of their life. In this kind of background, college English teaching simply work on grammar, and make all the classes just like lectures, all the multi-media thinking just like PPT replacement of blackboard. According to the investigation and interview done in the author's university, a large proportion of students are not satisfied with the way of teaching and the frequency of English classes. They are eager to get more English exposure out of class and they need a step to the development of life-long learning.

3) Students' English proficiency after college education is widely questioned. After CET-4 and CET-6, the students are still lacking of good performance in English application, like paper writing, daily and academic communication. 


\section{B. MOOC-based college English teaching}

MOOC is still on a controversial field right now. MOOC represents a modern way of learning which combines the thinking of Constructivism, Independent Learning, Flipped Learning, etc. [5,6]. MOOC-based college English teaching refers to a good combination of MOOC conception and college English teaching, which is a great way to deal with the problems confronted by college English teaching. Compared to traditional English teaching, MOOC-based English teaching has a lot of specialties and advantages in class designing, Internet-based interaction and freedom of learning in time and space $[7,8,9]$. It offers countless learning resources in modern way and makes it possible for language exposure and interaction between learners and teachers out of class [10]. If college teachers could make a good combination of MOOCbased English teaching and traditional English teaching, it will bring a lot of benefits to English learners in college.

Discussions on MOOC-based college English classes in China falls on two categories: complete promotion of MOOC or a combination of MOOC and FC (Flipped Classes). When the two categories are discussed, the papers offer more theoretical points than the empirical evidence.

In addition, MOOC-based college English teaching discussion is mainly from the perspective of conception and needs more consideration of teaching mode. According to Tyler's four elements (objective, content, construction and evaluation), we still need more empirical work to answer a number of questions, like: How to make MOOC-based college English teaching a complete system which includes objective, construction and more, not just some courses online; How to make a combination of flipped class and traditional class by the means of MOOC; How to make the MOOC-based college English teaching really interactive and acceptable for college students[11,12]

\section{THE EMPIRICAL STUDY}

Based on the above theoretical thinking, the author conducts an empirical study on MOOC-based college English teaching in her university. The university already has an online e-education platform, Blackboard, available to all the students and teachers. The designed aim of the study is to improve the students' comprehensive English proficiency by the way of MOOC-based college English teaching. And the discussions will be faithfully based on all the data and feedbacks from a one-semester experience.

To start the study, a designed course "College English" was put on Blackboard platform, and the students of chosen classes have the access to all the sources of the course. For one semester research, the course was divided into 8 units, which were closely related to the students' textbook. Each unit had a topic, related video, quiz, etc. The videos were recorded by the teacher herself with the help of some software like Camtasia Studio. The videos were mainly about language skills or the assistance to before and after class self-study, like grammar, sentence explanation, writing skills, etc. Each video lasted for less than 5 minutes and ended with some questions which could be used in class discussion. And the students were encouraged to use personal blog section and textbook-related

Sponsored by 2017 program of Center for Teaching and Learning Development, Shaanxi Normal University (JSJX2017L130). forum on Blackboard. The students had some self-study assignment and they needed to study online by themselves, then the class time allotment would include a section for discussion about online learning. In addition, the online quizzes and writing assignment were designed and used in the research.

The assessment mainly included two parts: classroom assessment and online assessment. Classroom assessment was given by teachers according to the students' class performance, like their involvement in class activities and their scores in classroom quizzes. And the online assessment was including two parts: online quizzes and online activity. The students took online quizzes each time after self-study, the quizzes just took several minutes and they were mainly multiple choice. The assessment and feedback would be given automatically to the students when they finished quizzing. And the scores would be recorded and given back to the teacher. For online activity, their involvement in blog, forum, etc was recorded and assessed.

The study also involved questionnaire. Before the course, in the middle of the course and after the course, the questionnaires are used in the students' classes to get some findings about their motivation, learning habit, attitude on different stages. And the questionnaire result will be compared with other evidences from the study.

\section{A. What the teacher does?}

The teacher designs the online course and makes the online resources for the whole semester systematic. The teacher needs to make sure each unit is closely related to the students' textbook and each unit has a topic. Besides, the related quizzes and writing section are designed. And the teacher will design class activities according to both the textbook and the assignment online. In addition, the teacher has the responsibility of recording the students' class performance and online performance, so that the final assessment will be objectively made.

\section{B. What the students do?}

- Make use of the online Course, including all the learning resources to finish self-study assignment. They will do all the before-class and after-class assignment and quizzes with the help of online resources, like the video and PPT.

- Take part in classroom activities, like classroom discussion, PowerPoint presentation, answering questions.

- Take part in online activities. They are required and encouraged to take part in online activities like blog, forum and online quiz.

\section{THE RESULTS AND DISCUSSION}

The research data was collected anonymously to ensure the objectivity. Quantitative data was collected by Likert Scale, mainly for the understanding of the students' attitude, motivation, learning habit, etc. Qualitative data was got from questionnaires, interviews and some other ways. The students' recorded scores and class performance were also considered. 
According to the quantitative and qualitative research, we got the following results and discussions:

\section{A. Quantitative Research}

As in Table I, the quantitative research shows some general and detailed attitudes. For general understanding, like Question 1, general attitude towards MOOC based English course, a large proportion of students are satisfied with MOOC-based English course and only 3\% shows complete negative attitude. For detailed information, like Question 2, attitude towards teachers' course design, and Question 3, attitude towards online video, we can clearly see most students are satisfied, esp. for course design, over 90\% choose "satisfied" or "very satisfied".

TABLE I. DETAILED DATA EXAMPLE

\begin{tabular}{|c|c|c|c|c|c|}
\hline Q & $\begin{array}{c}\text { Very } \\
\text { satis. }\end{array}$ & Satis. & $\begin{array}{c}\text { Not } \\
\text { sure }\end{array}$ & $\begin{array}{c}\text { Not } \\
\text { satis. }\end{array}$ & $\begin{array}{c}\text { Completely } \\
\text { not satis. }\end{array}$ \\
\hline 1 & 7 & 42 & 29 & 9 & 3 \\
\hline 2 & 61 & 27 & 0 & 2 & 0 \\
\hline 3 & 51 & 31 & 4 & 4 & 0 \\
\hline
\end{tabular}

And the students' performance data in MOOC-based classes are also positive. According to the comparison data, the students' involvement in MOOC-based course is much better than their involvement in traditional English classes. They are more active in class activities. They have more exposure to English for many reasons and they are willing to use blog and forum to communicate with others. These involvements also result in their better performance in classroom activities and quizzes.

As in Table II, the comparison data gives us some clue of the difference. To Question 1, the exposure to English: Before the MOOC-based course, students don't have much exposure to English; in contrast, when the MOOC-based course is adopted, they obviously expose themselves to English a lot. There is dramatic difference due to the course design, assignment requirement and some other factors. The interview shows the convenience of mobile App and peer pressure also greatly contributes to this. To question 2 , how often they take part in classroom activity: Before the MOOC-based course, $70 \%$ of students never take part in classroom activity. They just sit in class and listen to the teachers' lecture. While in the MOOC-based course, the before-class activity and early exposure to English help them to get ready and be confident in classroom activity. They are undoubtedly more active.

If we consider the students' progress from the point of grade, the evidence is also strong, as is showing in Table III, the students' score of writing. Based on MOOC-based online writing practice and automatic checking, the students have more chance to practice writing and get feedback quickly in the empirical study. This kind of instant feedback arouse their interests and help them in self-correcting. The lowest writing score was promoted from 45 to 60 , and the mean changed from 68.333 to 73.667. The standard deviation which changes from 11.178 to 8.133 is also a positive evidence of the overall writing improvement of the whole class. The progress in quizzes is also great. The mean was promoted 10 points, and the standard deviation reduces two points. That's partly because the quiz notice on Blackboard, easy-to-use online exercises and frequent exposure to English make them more prepared and confident for all the quizzes in class.

TABLE II. COMPARISON DATA EXAMPLE

\begin{tabular}{|c|c|c|c|c|c|}
\hline Q & $\begin{array}{c}\text { very } \\
\text { often }\end{array}$ & often & $\begin{array}{c}\text { some } \\
\text { time }\end{array}$ & seldom & never \\
\hline Exposure Before & 5 & 9 & 18 & 45 & 13 \\
\hline Exposure After & 58 & 23 & 9 & 0 & 0 \\
\hline Activity Before & 4 & 7 & 7 & 9 & 63 \\
\hline Activity After & 63 & 20 & 7 & 0 & 0 \\
\hline
\end{tabular}

TABLE III. SCORE OF WRITING AND QUIZZES

\begin{tabular}{|c|c|c|c|c|c|}
\hline & N & Lowest & Highest & Mean & Standard Deviation \\
\hline Before & 90 & 45 & 84 & 68.333 & 11.178 \\
\hline After & 90 & 60 & 86 & 73.667 & 8.133 \\
\hline
\end{tabular}

During this empirical study, the students are generally satisfied with the course and make obvious improvement. The quantitative analysis above does reveal the students' great performance from the point of attitude, English learning habit, and score. Besides all the improvement evidence, the research data and information also show something negative which are worthy of thinking.

1) The top students show less improvement compared to students of other levels. The interview and questionnaire evidence shows that they have always been willing to learn English through all different means at any time. And some of them have their own way of English learning. So the introduction and application of modern technology in English classes seems not so effective for them. Their inner motivation and self-study play major role in their English learning.

2) The students are generally satisfied with MOOCbased English course, but in some aspects, the answers are partly related to the teacher herself. Like the teacher's attitude towards the students, the teachers' personal style in course designing and the teacher's performance in video, these elements strongly influence students' feelings, questionnairechoices and their actions online and offline. For some students the decisive factors are not the new technology or style, but the teacher. And some students clearly say that their own teacher in the online video interests them more than any other elements.

3) The students commonly think the MOOC-based course offers something new and interesting and they are willing to learn. And they make choices in questionnaires in accordance with this point. But in terms of actual study, they are willing to find excuses and sometimes use technical way to cheat in online learning. So the inspection, supervision and assessment are very important in MOOC-based courses. The teacher has to adopt a lot of effective measures to ensure the students involvement in each part of the online courses.

\section{B. Qualitative Research}

The empirical study of MOOC-based course reveals students' interest and improvement in English learning. By 
interview research and other evidence, we can see that MOOCbased teaching has the following positive effects:

- MOOC-based course offers time and place flexibility. A large proportion of students have the view that time and place flexibility makes them more willing to learn. They could make use of some of their fragment time to learn. They feel a kind of satisfaction from self-control.

- In MOOC-based course, online resources are good assistance for preview and make them ready and more confident in class performance. Many students think the videos and other materials offer them valuable information and help them to understand better. They are also more confident in quizzes.

- In MOOC-based course, online communication is a good way to practice English and learn English by using. A lot of students think online forum and blog make a very good virtual community, which creates an authentic language environment for them. When there is a suitable topic, they have the willingness to use English to express themselves and get responses.

The quantitative and qualitative analysis of the study does show some great advantages of MOOC-based college English model. We can clearly see the wide acceptance, the willingness to learn, and advantages in communication and review. But besides all the positive effects, the data and evidence also reveal the following problems, which also need consideration.

1) The course requires a lot of teacher's devotion. In China, the students are trained to learn by listening in class since primary school. It's not easy for them to learn by themselves. In MOOC-based course, the teacher plays an important role in course design, assignment checking and activity conduction. It's obvious that it requires more devotion from the teacher compared to traditional course.

2) MOOC-based course design needs to be combined with classroom activity. The teacher has to make the course a systematic and complete course, not just some online resources Only when all the videos, PPT and materials are related to the teacher's class, they could be meaningful and could arouse the students' interests and responsibility. If we just take MOOC as online collection of videos and resources, the students will not take them seriously, because they have plenty of resources online, which they never care.

3) A good combination of PC and App is necessary. During this empirical study, the university's Blackboard platform has an App version. It's easy to see that the students like to get online by App on their phones. The data and interviews show that a large proportion of students prefer using App. It's easy and convenient. In this phone time, they could easily get into course checking and studying at any moment by phone. They enjoy this kind of game-like and relaxing way of learning. From this point, PC is not as welcome as App on phone.
4) This modern way of learning and teaching needs some basic knowledge of computer and technology. This will be a limitation and barrier in promoting MOOC-based course because some teachers and students are not familiar with computer and modern trend, especially in some remote areas. The lacking of facilities and computer skills will to some extent block the way of using MOOC-based English courses and will definitely influence the teacher and students' performance and achievement in any MOOC-based courses.

\section{CONCLUSION}

This present study examines MOOC-based college English model. The paper reviews the basic situation of college English teaching in China and conducts an empirical study for one semester to explore MOOC-based teaching and learning model. Results and analysis reveal that students are willing to take MOOC-based English courses and have better involvement and performance compared to traditional English courses. Students enjoy the convenient learning on Apps. Findings also indicate that MOOC-based English courses offer flexibility and have great advantage in writing, communicating and language exposure. However, the analysis of data shows that this new technology-related course model has little influence on top students and it is not easy to be supervised. In addition, the course requirements of computer skills and teachers' devotion may barrier its development. Moreover, MOOC-based course requires systematic course design which is, to some extent, more important than technology application.

\section{REFERENCES}

[1] Richey, R.C., "Reflections on the 2008 AECT definitions of the field," Technology Trends, Vol 1, 2008

[2] Perna, L. W., Ruby, A., "Life cycle of a million MOOC users," Invited presentation at the MOOC Research Initiative Conference. Arlington, Texas, 2013.

[3] Wang Shouren, "Scientific view of college English teaching reform," Foreign Language World, Vol 6, 2013

[4] Chen Xuezhen, "The International development of MOOC and its enlightment on Chinese college English teaching revolution," Journal of Neimenggu Normal University, Vol 45, pp.74-77, 2016.

[5] Li Manli, "Exploring the instructional design principles of MOOCs, " Tsinghua Journal of Education, Vol 8, 2013

[6] Lu Hayan, "Feasibility analysis on the application of micro-class based 'flipped classroom' mode in college English teaching", ComputerAssisted Foreign Language Education, vol.158, 2014

[7] Zou Jingping, "MOOC's spirit is more important than forms," Distance Education in China, Vol 8, 2013

[8] Hu Jiehui, Wu Zhongjie, "MOOC-based college English flipped classroom instruction model," Computer-Assisted Foreign Language Education, vol. 160, pp. 40-45, 2014

[9] Kathleen F, "Upside down and inside out: flip your classroom to improve student learning", Learning and Leading in Technology, vol. 6, 2012

[10] Chen Bingbing, "MOOCs: contributions and dilemmas," ComputerAssisted Foreign Language Education, Vol 3, 2014

[11] Tyler R. W., Basic Principles of Curriculum and Instruction. Chicago: The University of Chicago Press, 1949

[12] Tian Xiaolei, "Research on creating micro-blog for college English teaching", Foreign Language Education, vol. 36, pp.69-72, 2015 